\title{
Effect of Online Social Networking Sites Usage on Academic Performance of University Students in Uganda
}

\author{
Peter Jegrace Jehopio \\ Department of Planning and \\ Applied Statistics \\ Makerere University
}

\author{
Ronald Wesonga \\ Department of Planning and \\ Applied Statistics \\ Makerere University
}

\author{
Douglas Andabati Candia \\ Department of Planning \\ and Applied Statistics \\ Makerere University
}

\begin{abstract}
Online social networking site (OSNS) like any technological innovation provides an opportunity for quick and easy access to information. As to whether the information obtained provides additional academic knowledge to students is hypothesized and measured by their academic performance in school. This study provides evidence to the ongoingdebate of whether the use of OSNS among students improves academic performance of students. Findings from the study show that the effect of OSNS usage on academic performance was significant $(p<0.05)$. Farther, the study demonstrated that for better academic performance, the optimum proportion of study time that a student may spend on OSNS usage was 25 percent. Students who manage their time well were morelikely to perform better than those who did not, by up to 48 percent. Furthermore, students who used OSNS more for academic than for non-academic purposes were more likely to perform better academically, by up to 11 percent. Regarding student majors: science-based majors tend to benefit more from OSNS usage compared to arts-based majors, by up to 50 percent. Student general characteristics (being male or female, married or single) and student-preferred mode of learning (using traditional, hybrid or online approach) were not significant in this study. In conclusion, use of OSNS by students at universities, when properly regulated results in better academic performance.
\end{abstract}

\section{Keywords}

Online Social Networking, Academic Performance, Logistic Regression, Uganda.

\section{INTRODUCTION}

The usage of online social networking sites (OSNS) such as Facebook, WhatsApp and Instagram is increasing among students $[1,2]$. Students useOSNS to share learning resources, collaborate and post content online, manage and coordinate schedules, gain motivation for serious studies, participate in peer education, socialize and enjoy a sense of community belonging, communicate with their instructors, gratify themselves and get entertainment [3-8].

Numerous studies have demonstrated that through usingOSNS, students achieve better academic performance [913]. On the other hand, unwarranted use of OSNSmay negatively influence students' academic performance $[5,14-$ 19].

Consensus on whether the use of online social networking (OSN) among students improves academic performance of user students or not is yet to be arrived at[20-22]The purpose of this study was, therefore, to investigate the effect of online social networking usage on student academic performance among university students in Uganda; specifically to assess the direct effect of OSNS usage and study the indirect effect on academic performance; basing on student general characteristics and, whether this be the case with upperclassmen (people who spend significantly more time using technology for academic and work-related purposes) or underclassmen (people who spend significantly more time using technology for non-academic purposes), student time management ability, student major (arts or sciences) and student preferred mode of learning (using traditional, hybrid or online).

\subsection{Literature Review}

The use of popular online social networking sites such as Facebook, WhatsApp, Instagram, Snap Chat, Twitter and LinkedIn is today ubiquitous, especially among students. Students nowadays spend much time on social networks [23]For example, it has been observed that students in Serbia spend a daily average of 2.76 hours on Facebook [4]while students in Ghana spend over eight hours daily on WhatsApp Messenger [24]On the use of technology, often students fail to regulate themselves to rightly balance between academic and non-academic usage [25-27][15] in a study on college student technology use and academic performance found that 75 percent of technology use among students is for non-academic but rather for leisure purposes.

Regarding academics, students use OSNS to access and share learning resources $[3,6,18,28]$, collaborate and post content online [29], manage and coordinate schedules [5, 8, 30, 31] gain motivation towards serious academic studies [5, 32]; participate in peer education through interaction with each other [1, 2, 33]; socialize and enjoy a sense of community belonging [34-36], communicate with their instructors [37, 38], gratify themselves [39] and get entertainment [7].

Through OSN, students institute cooperation with their peers and facilitate knowledge transfer from individual to other group members. Furthermore, students use OSN to discuss academics $[1,11]$. Accordingly, OSN facilitates students to engage in knowledge-sharing, discussion, easier access to information and gain motivation to study [1]By using OSN, a student is likely to gain motivation to study for better academic performance, given that a segment of students lack the motivation to study outside of educational institution. Furthermore, when instructors place learning resources and notifications important for a subject onto an OSN site, the result is that students more often get in contact with the resources [32, 40, 41], which, likely, they end up exploring for better academic performance.

It has been acknowledgedthat OSN sites provide an important background for social, emotional and cognitive development 
of young people [42]. By means of OSN students manage the fulfillment of their daily activities such as going to lectures and performing tasks efficiently and sustainably [8]Once a student can well manage his schedules, he is likely to significantly improve in academic performance. Yet, another usefulness of the ONS sites is that through the sites, students establish communication avenues with their instructors, gain greater motivation to learn, which often lead to better learning outcomes [43, 44]. On the OSNsites, instructors may post required course materials, useful multimedia contents and necessary information pertaining to the course and in this place students leave their comments, opinions, and suggestions.

Drawing from the ensuing discourse, a number of scholars have observed that under the influence of OSN, students achieve better academic performance [9-13, 45]. This is because OSN sites facilitate the immediate transfer of knowledge and learning resources among students anywhere, anytime. Social media supports a more reflective approach to learning but also offer the opportunity to make teaching more practical and application-oriented [46]. [22]Investigated the influence of OSN and concluded that online socializing does not reduce students study time, instead it helps them to get the latest study related information, share course and class schedules.

While OSN may be a boon, its unwarranted use can negatively influence students' academic performance $[2,5$, 14-19, 47]through shifting focus away from concentration on academics to, say, online entertainment and non-academic socialization. Students who use OSN much are likely to engage in multitasking (doing several academic or other activities concurrently) which diminishes focus and often leads to poor academic performance [48]Moreover, social networking can become addictive, distractive and have negative impact on social interactions, emotional health or cause burnout [2]It has also been noted that OSN leads to reduction in face-to-face interaction among people, sleep problems, anxiety, depression, lack of privacy, fake identity, time consumption and, not infrequently, addiction to social media usage that interferes with performing daily tasks [49, 50]Indeed, on an OSN site, there may be so much information overload that it becomes difficult to distinguish the useful from the useless [31]. Students who spend much time on OSN tend to procrastinate and postpone academic work more often [51-53] It has been shown that students who use OSN sites everyday have significantly lower grades than those who do not [54]. [55]Investigated phone usage and revealed that mobile phone usage significantly influence academic performance among male and female senior secondary school students. Similarly,[56]researched and found a lowering in academic performance among students who use ONS more.

There is an ongoing debate as to whether the use of OSN among students improves academic performance of user students or not does persist[20-22, 57]. On one hand, OSN is seen to improve academic performance of student users [22, $46,58]$ while on the other it does negatively impact on academic performance $[20,51,56,59]$. Aside from the ensuing arguments, [60]found that the reverse is the case, i.e. it is OSN usage that influences academic performance: the lower the academic performance the more the recourse to OSN. Yet, there are scholars who argue that OSN usage among students has neither positive nor negative effect on student academic performance $[15,61]$, whether this be among upperclassmen (people who spend significantly more time using technology for academic and work-related purposes) or underclassmen (people who spend significantly more time using technology for non-academic purposes); whether male or female student $[62,63]$ whether there exist differences in learning styles or not [64]. According to [65], performance is a function of attention span, time management skills, student characteristics, academic competence and time spent on OSN. Student characteristics include age, gender, marital and family status, work requirements, major (arts or sciences based academic program of study that a student is enrolled in) and preferred mode of learning (using traditional, hybrid or online learner using technology of a student). Attention span refers to the length of time for which a student is able to concentrate on a particular academic activity, say a one-hour lecture.

\section{METHODOLOGY}

To achieve the objectives of this study, data were collected in May 2016 from 312 students of Makerere University using stratified cluster sample design. Students offering arts, sciences, male and female were targeted. Data were collected on the different characteristics as presented in Figure 1 with academic performance transformed into a binary outcome.Primary data were collected by means of a selfreported questionnaire.

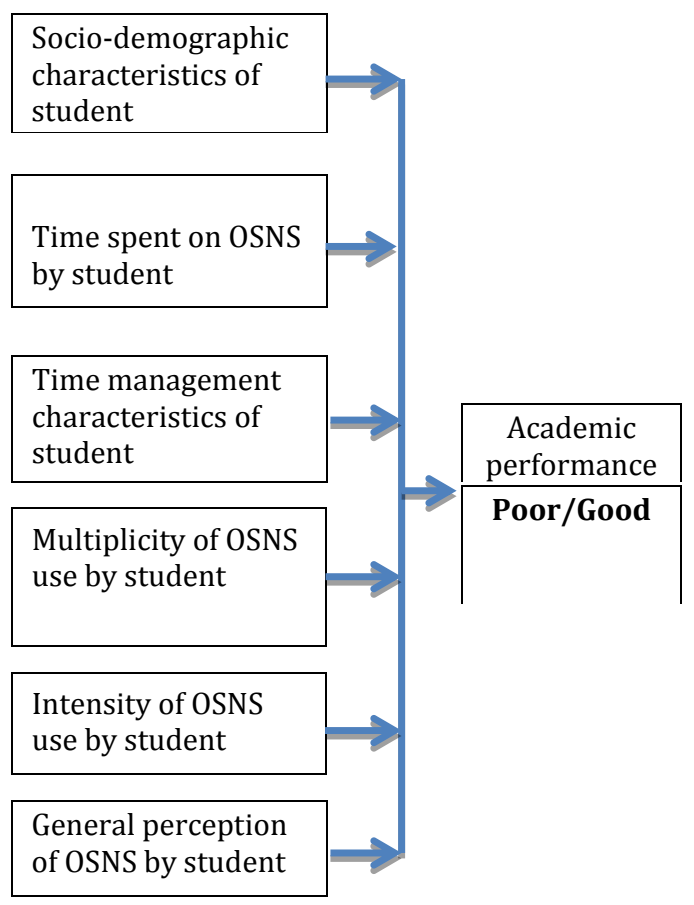

Figure 1:Conceptual framework for effect of online social networks on student academic performance

Fifty two $(52 \%)$ percent of the respondents were male and 48 percent female. The majority of the respondents $(74 \%)$ were students majoring in science-based disciplines while the rest (26\%) were majoring in arts-based disciplines. The survey questions were designed to measure the constructs focusing on various plausible independent variables including student socio demographic characteristics, time spent on OSNS, time management, multiplicity of OSNS usage, intensity of OSNS usage and general perception of OSNS.

The data was analyzed using STATA Version 13.0 (StataCorp, 2013). Descriptive statistics were invoked for description of respondent characteristics. At bivariate level, simple logistic regression and cross tabulation were used. Significant independent variableswere considered for 
multivariate analysis performed using structural equation modeling approach.

\section{FINDINGS}

\subsection{Description of respondents}

Findings from the studyare presented beginning with the characteristics of respondents, then the relationships between academic performance and the potential determinants and lastly the model for OSNSusage on academic performance.

In Table 1 a description of the characteristics of the respondents to the study is made.

Table 1: Characteristics of respondents

\begin{tabular}{|c|c|c|}
\hline Variable & $\begin{array}{r}\text { Percentag } \\
\text { e }\end{array}$ & $\mathbf{n}$ \\
\hline \multicolumn{3}{|l|}{ Age } \\
\hline$<=20$ years & 36.55 & $\begin{array}{r}10 \\
6\end{array}$ \\
\hline$>20$ years & 63.45 & $\begin{array}{r}18 \\
4\end{array}$ \\
\hline \multicolumn{3}{|l|}{ Gender } \\
\hline Male & 52.22 & $\begin{array}{r}15 \\
3\end{array}$ \\
\hline Female & 47.78 & $\begin{array}{r}14 \\
0\end{array}$ \\
\hline \multicolumn{3}{|l|}{ Marital status } \\
\hline Married & 7.33 & 22 \\
\hline Single & 92.67 & $\begin{array}{r}27 \\
8\end{array}$ \\
\hline \multicolumn{3}{|l|}{ Family status } \\
\hline Has no children & 94.8 & $\begin{array}{r}23 \\
7\end{array}$ \\
\hline Has children & 5.2 & 13 \\
\hline \multicolumn{3}{|l|}{ Work requirements } \\
\hline Spends $<=8$ hours & 68.15 & $\begin{array}{r}18 \\
4\end{array}$ \\
\hline Spends $>=8$ hours & 31.85 & 86 \\
\hline \multicolumn{3}{|l|}{ Time management skills } \\
\hline Yes & 65.65 & $\begin{array}{r}19 \\
3\end{array}$ \\
\hline No & 34.35 & $\begin{array}{r}10 \\
1\end{array}$ \\
\hline \multicolumn{3}{|l|}{ Student major } \\
\hline Arts & 26.48 & 76 \\
\hline Sciences & 73.52 & $\begin{array}{r}21 \\
1\end{array}$ \\
\hline \multicolumn{3}{|l|}{ Mode of learning } \\
\hline A purely face-to face student & 67.01 & $\begin{array}{r}19 \\
5\end{array}$ \\
\hline $\begin{array}{l}\text { An hybrid (ie sometimes an online } \\
\text { student }\end{array}$ & 31.62 & 92 \\
\hline A purely an online student & 1.37 & 4 \\
\hline \multicolumn{3}{|l|}{ Time spent on OSNS } \\
\hline Don't use & 2.01 & 6 \\
\hline 1-2 hours & 22.82 & 68 \\
\hline 3-4 hours & 22.82 & 68 \\
\hline
\end{tabular}

\begin{tabular}{lrr}
\hline $5-6$ hours & 15.44 & 46 \\
$>6$ hours & 36.91 & 11 \\
& & 0
\end{tabular}

Multiplicity of OSNS uses

$\begin{array}{lrl}\text { Strongly agree } & 27.3 \quad 80\end{array}$

Agree $\quad 34.81 \quad 10$

Neutral $17.41 \quad 51$

Disagree $\quad 14.68 \quad 43$

$\begin{array}{lll}\text { Strongly disagree } & 5.8 & 17\end{array}$

Heavy use of OSNS

Very high $\quad 15.31 \quad 45$

High $\quad 16.67 \quad 49$

$\begin{array}{lll}\text { Moderate } & 22.45 \quad 66\end{array}$

Low $\quad 20.75 \quad 61$

Very low $\quad 24.83 \quad 73$

General perception about OSNS

(usefulness)

$\begin{array}{lll}\text { Strongly agree } & 53.69 & 16\end{array}$

Agree $\quad 33.56 \quad 10$

Neutral $\quad 9.4 \quad 28$

$\begin{array}{lll}\text { Disagree } & 2.35 & 7\end{array}$

Strongly disagree $\quad 1.01 \quad 3$

Academic performance

$\begin{array}{lll}\text { Poor } & 38.33 & 11\end{array}$

$\begin{array}{lll}\text { Good } & 61.67 \quad 18\end{array}$

According to results in Table 1 , more than half of the respondents were above 20 years $(63.5 \%)$ with only $36.5 \%, 20$ years and below. Regarding gender, the highest proportion was males $(52.22 \%)$ then females $(47.78 \%)$. As for family status only $5.2 \%$ had children with the majority (94.8\%) having none. Majority of the respondents worked for 8 hours or less $(68.15 \%)$ with only $31.85 \%$ working beyond 8 hours. Pertaining to time management, only $34.35 \%$ of respondents had poor time management skills with the rest $(65.65 \%)$ having good time management skills. Majority of the students interviewed were majoring in Science disciplines $(73.52 \%)$ with only $26.48 \%$ majoring in Arts. Regarding the mode of learning, majority of the respondents preferred purely face-toface learning $(67.01 \%)$ with only $31.62 \%$ preferring hybrid and $1.37 \%$ purely online. As regards time spent on OSNS, the highest proportion spent over 6 hours $(36.91 \%)$ with only $2.01 \%$ not connected to OSNS. As for multiplicity of OSNS usage, the highest proportion $(34.81 \%)$ agreed to using multiple OSNS followed by those who strongly agreed $(27.3 \%)$ with the least being those who strongly disagree $(5.8 \%)$. On intensity of OSNS usage, $15.31 \%$ reported that they were heavy OSNSusers (i.e. use OSNS for over two (2) hours out of eight (8) working hours) while $24.83 \%$ reported that they were low users. Regarding respondents" general perception about OSNS, 53.69\% strongly agreed that it's useful with only $1.01 \%$ strongly disagreeing. As for academic performance, majority of the respondents were good performers $(61.67 \%)$ and only $38.33 \%$ were poor performers. 


\subsection{Relationship among predictors of academic performance}

We present tests of relationship between duration and potential indirect predictors of academic performance in Table 2 .

Table 2: Duration of OSNS usage and associated factors

\begin{tabular}{|c|c|c|c|c|c|c|}
\hline & & \multicolumn{5}{|c|}{ DURATION OF OSNS USAGE } \\
\hline & & $0-2 \mathrm{hrs}$ & 3-4 hrs & $5-6 \mathrm{hrs}$ & $7-8 \mathrm{hrs}$ & 9 plus hr \\
\hline \multirow[t]{3}{*}{ Enough time (tm8) } & Yes & 28.18 & 20.44 & 17.68 & 4.97 & 28.73 \\
\hline & No & 14.41 & 24.32 & 16.22 & 15.32 & 29.73 \\
\hline & & \multicolumn{5}{|c|}{$\operatorname{chi} 2(4)=14.5288 \quad \operatorname{Pr}=0.006$} \\
\hline \multirow[t]{3}{*}{ Checking OSNS (as3) } & Yes & 17.22 & 23.44 & 16.27 & 10.05 & 33.01 \\
\hline & No & 38.37 & 17.44 & 19.77 & 5.81 & 18.60 \\
\hline & & \multicolumn{5}{|c|}{$\operatorname{chi} 2(4)=18.7230 \quad \operatorname{Pr}=0.001$} \\
\hline \multirow[t]{3}{*}{ Sex } & Male & 27.33 & 23.33 & 16.00 & 11.33 & 22.00 \\
\hline & Female & 20.14 & 19.42 & 17.99 & 6.47 & 35.97 \\
\hline & & \multicolumn{5}{|c|}{$\operatorname{chi} 2(4)=9.0398 \quad \operatorname{Pr}=0.060$} \\
\hline \multirow[t]{4}{*}{ Mode of learning (sc5) } & A purely face-to face & 27.08 & 23.44 & 18.23 & 8.85 & 22.40 \\
\hline & An hybrid & 15.56 & 20.00 & 16.67 & 5.56 & 42.22 \\
\hline & A purely an online student & 0.00 & 0.00 & 0.00 & 25.00 & 75.00 \\
\hline & & \multicolumn{5}{|c|}{$\operatorname{chi} 2(8)=19.8385 \quad \operatorname{Pr}=0.011$} \\
\hline \multirow[t]{3}{*}{ Power effect (sc91) } & Yes & 13.20 & 19.80 & 20.81 & 10.66 & 35.53 \\
\hline & No & 42.39 & 25.00 & 10.87 & 5.43 & 16.30 \\
\hline & & \multicolumn{5}{|c|}{$\operatorname{chi} 2(4)=37.8547 \quad \operatorname{Pr}=0.000$} \\
\hline \multirow[t]{3}{*}{ Status updates (sc92) } & Yes & 12.59 & 17.04 & 20.00 & 11.85 & 38.52 \\
\hline & No & 31.82 & 26.62 & 14.94 & 6.49 & 20.13 \\
\hline & & \multicolumn{5}{|c|}{$\operatorname{chi} 2(4)=26.4608 \quad \operatorname{Pr}=0.000$} \\
\hline \multirow[t]{3}{*}{ Primary means of comms (sc93) } & Yes & 18.37 & 19.90 & 19.39 & 10.71 & 31.63 \\
\hline & No & 31.91 & 24.47 & 13.83 & 5.32 & 24.47 \\
\hline & & \multicolumn{5}{|c|}{$\operatorname{chi} 2(4)=10.0353 \quad \operatorname{Pr}=0.040$} \\
\hline \multirow[t]{6}{*}{ OSNS Enjoyment (pb1) } & Strongly agree & 14.16 & 20.35 & 17.70 & 10.62 & 37.17 \\
\hline & Agree & 17.65 & 25.49 & 15.69 & 10.78 & 30.39 \\
\hline & Neutral & 41.30 & 15.22 & 23.91 & 6.52 & 13.04 \\
\hline & Disagree & 36.36 & 31.82 & 13.64 & 0.00 & 18.18 \\
\hline & Strongly Disagree & 62.50 & 12.50 & 12.50 & 0.00 & 12.50 \\
\hline & & \multicolumn{5}{|c|}{$\operatorname{chi} 2(16)=35.8466 \operatorname{Pr}=0.003$} \\
\hline \multirow[t]{6}{*}{ OSNS useful (pb2) } & Strongly agree & 15.72 & 17.61 & 18.87 & 12.58 & 35.22 \\
\hline & Agree & 27.84 & 26.80 & 14.43 & 6.19 & 24.74 \\
\hline & Neutral & 40.74 & 29.63 & 18.52 & 0.00 & 11.11 \\
\hline & Disagree & 57.14 & 28.57 & 0.00 & 0.00 & 14.29 \\
\hline & Strongly Disagree & 33.33 & 0.00 & 66.67 & 0.00 & 0.00 \\
\hline & & \multicolumn{5}{|c|}{$\operatorname{chi} 2(16)=35.6729 \operatorname{Pr}=0.003$} \\
\hline \multirow[t]{3}{*}{ Improve performance (pb37) } & Strongly agree & 13.79 & 13.79 & 24.14 & 10.34 & 37.93 \\
\hline & Agree & 19.15 & 27.66 & 9.57 & 10.64 & 32.98 \\
\hline & Neutral & 28.07 & 21.05 & 19.30 & 3.51 & 28.07 \\
\hline
\end{tabular}




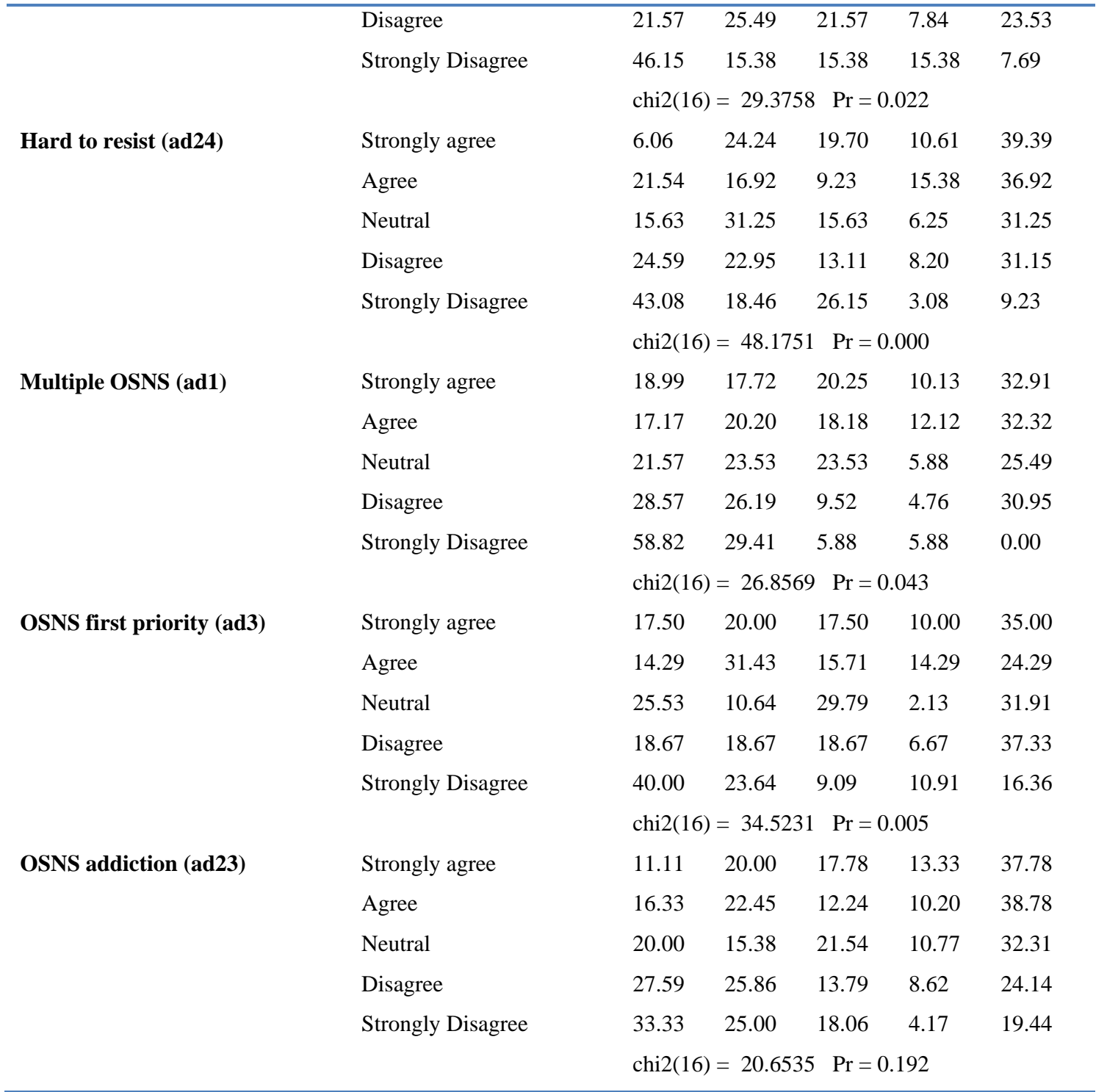

Initially, we established that there was no significant direct relationship between potential predictors and academic performance. We further performed the chi-square tests for potential predictors and time spent on OSNS and established that all potential factors, except two (sex and level of addiction to OSNS) were significant $(\mathrm{p}<0.05)$.

Table 2 shows that $28.73 \%$ of the students who consulted OSNS for their assignments spent over 9 hours on OSNS as much $33.01 \%$, who often checked OSNS in the middle of working on an assignment. Further, students who reported that they learned best while using purely online materials (75\%), spent over 9 hours on OSNS. Power fluctuations affected usage of OSNS and subsequently, academic performance; $35.53 \%$ of the students who reported to be completely out of touch when the power was off, spent over 9 hours on OSNS.

Findings also show that students who spent at least 9 hours on OSNS had the following characteristics: $38.52 \%$ admitted updating their statuses and checking that of their friends on a daily basis, $31.63 \%$ used OSNS as ones primary means of communication, $37.17 \%$ used OSNS for enjoyment, $37.93 \%$ used OSNS to improve their academic performance, $39.39 \%$ found it hard to resist the use of OSNS, $32.91 \%$ agreed to use of multiple OSNS and 35\% strongly agreed to have postponed an activity for OSNS.

\subsection{Model ofOSNSusage on Academic Performance}

The study found that the effect of heavy OSNSusage on student academic performance to be statistically significant (presented in Table 3 which follows).

Table 3: Model of academic performance and OSNS usage

\begin{tabular}{lcccr}
\hline $\begin{array}{l}\text { Academic } \\
\text { Performance }\end{array}$ & $\begin{array}{c}\text { Odds } \\
\text { Ratio }\end{array}$ & P>z & & 95\% C.I \\
\hline Heavy use & & & & \\
Strongly Agree & 1.00 & - & - & - \\
Agree & 0.51 & 0.14 & 0.21 & 1.24 \\
Neutral & 0.47 & 0.08 & 0.20 & 1.08 \\
Disagree & 0.66 & 0.35 & 0.28 & 1.57 \\
Strongly Disagree & 0.39 & 0.03 & 0.17 & 0.89 \\
\hline
\end{tabular}


From Table 3, there exists a significant association between heavy use of OSNS and academic performance.

Table 4: Model of Academic Performance and potential direct predictors

\begin{tabular}{|c|c|c|c|c|}
\hline $\begin{array}{l}\text { Academic } \\
\text { Performance }\end{array}$ & OR & $\mathbf{P}>\mathbf{Z}$ & \multicolumn{2}{|c|}{ 95\% C.I } \\
\hline $\begin{array}{l}\text { Time } \\
\text { management } \\
\text { skills }\end{array}$ & & & & \\
\hline Yes & & & & \\
\hline No & 0.49 & 0.05 & 0.24 & 0.99 \\
\hline $\begin{array}{l}\text { Member of } \\
\text { multiple } \\
\text { OSNS }\end{array}$ & & & & \\
\hline Strongly agree & & & & \\
\hline Agree & 2.13 & 0.09 & 0.90 & 5.05 \\
\hline Neutral & 1.84 & 0.25 & 0.65 & 5.21 \\
\hline Disagree & 1.60 & 0.39 & 0.55 & 4.68 \\
\hline $\begin{array}{l}\text { Strongly } \\
\text { Disagree }\end{array}$ & 5.00 & 0.05 & 1.01 & 24.60 \\
\hline $\begin{array}{l}\text { Heavy use of } \\
\text { OSNS }\end{array}$ & & & & \\
\hline Strongly agree & & & & \\
\hline Agree & 0.42 & 0.16 & 0.12 & 1.39 \\
\hline Neutral & 0.29 & 0.04 & 0.09 & 0.93 \\
\hline Disagree & 0.48 & 0.25 & 0.14 & 1.67 \\
\hline $\begin{array}{l}\text { Strongly } \\
\text { Disagree }\end{array}$ & 0.20 & 0.01 & 0.06 & 0.66 \\
\hline
\end{tabular}

From Table 4,forstudents who had good time management skills, the odds of performing well were higher compared to students with poor time management skills. Regarding being a member of multiple OSNS, for students who strongly disagreed, the odds of performing well academically were higher compared to students who strongly agree.

With reference to heavy use of OSNS, for students who strongly disagreed, the odds of performing well academically were lower compared to those of students who strongly agreed. Similarly, for students who were neutral regarding heavy use of OSNS, the odds of performing well academically were lower compared to those of students who strongly agreed.

\section{DISCUSSION OF FINDINGS}

This study focused on the effect of online social networking site usage on student academic performance in Uganda; specifically assessing theeffect of indirect effect viaOSNS usage and direct effect on academic performance; basing on student general characteristics and, whether this be the case with upperclassmen (people who spend significantly more time using technology for academic and work-related purposes) or underclassmen (people who spend significantly more time using technology for non-academic purposes), student time management capability, student major (arts or sciences) and student preferred mode of learning (using traditional, hybrid or online). To study the direct and indirect effects, we employed structural equation models as presented in Table 3 and Table 4.

From the study, the effect of OSNS usage on academic performance was significant $(\mathrm{p}<0.05)$. This isin agreement with several other scholars:[9-13, 43, 45]Farther, this study demonstrated that for better academic performance, the optimum proportion of study time that a student may spend on OSNS usage is approximately twenty-five percent $(25 \%)$;note takenof students who spend approximately two (2) hours on OSNS usage out of eight (8) study hours in a day. It is probable that the students whose OSNS usage are above the optimum, likely tend towards addiction to social media usage leading to interference with their daily tasks performance synchronous with studies by $[49,50]$ Besides, it is likely that the students whose OSNS usage are above the optimum do engage on multitasking which diminishes focus and often leads to poor academic performance [48, 56]. Moreover, students who spend much time on OSNS tend to procrastinate and postpone academic work more often [51-53].

Consistent with the study by [8]students who manage their time well reported better academic performance. This study found that students who manage their time well are likely to perform better than those who do not,by up to 48 percent.Farther, the study found that students who reported that they use OSNS more for academic purposes also reported better academic performance, by up to 11 percent compared to those who engage in OSNS usage for more for non-academic purposes.

Consideringthe student major: with regards to good academic performance: science-based majors tend to benefit more from OSNS usage compared to arts-based majors, by up to 50 percent. This is likely because science-based studies are factual. The science information found on the Internet is easily verifiable while the arts based information may be debatable.

\section{CONCLUSION}

The amount of time spent using online social networking sites (OSNS) significantly affects student academic performance. For good academic performance, the optimum proportion of study time that a student may spend on OSNS usage is approximately twenty-five percent $(25 \%)$. Students who manage their time well are likely to perform better than those who do not, by up to 48 percent. Furthermore, students who use OSNS more for academic than for non-academic purposes are likely to perform better academically, by up to 11 percent. Regarding student majors: science-based majors tend to benefit more from OSNS usage compared to artsbased majors, by up to 50 percent. However, demographic characteristics of the students such as sex and age do not affect their OSNS usage and subsequently their academic performance.The study recommends that educational institutions should institute compulsory OSNS courses for all students to enable them manage and refocus OSNSso as to benefit their academic performance.

\section{REFERENCES}

[1] L. Dragan, "Correlation between Facebook use for educational purposes and academic performance of students," Computers in Human Behavior, vol. 61, p. 313e320, 2016.

[2] A. Kitsantas, N. Dabbagh, D. S. Chirinos, and H. Fake, "College students' perceptions of positive and negative effects of social networking," Social Networking and Education, p. 225e238 2016. 
[3] C. C. Barczyk and D. G. Duncan, "Facebook in higher education courses: an analysis of students' attitudes, community of practice, and classroom community," International Business and Management, vol. 6, p. 1e11, 2013.

[4] B. Janković, M. Nikolić, J. Vukonjanski, and E. Terek, "The impact of Facebook and smart phone usage on the leisure activities and college adjustment of students in Serbia," Computers in Human Behavior, vol. 55, 2016.

[5] R. Junco, "Student class standing, Facebook use, and academic performance," Journal of Applied Developmental Psychology, vol. 36, p. 18e29, 2015.

[6] P. Rambe, "Activity theory and technology mediated interaction: cognitive scaffolding using question-based consultation on Facebook," Australasian Journal of Educational Technology, vol. 28, p. 1333e1361, 2012.

[7] S. K. Sharma, A. Joshi, and H. Sharma, "A multianalytical approach to predict the Facebook usage in higher education," Computers in Human Behaviour, vol. 55, p. 340e353, 2016.

[8] M. Thongmak, "Factors determining learners' acceptance of Facebook in a higher education classroom," 6, vol. 3, p. 316e331, 2014.

[9] S. Ainin, M. M. Naqshbandi, S. Moghavvemi, and N. I. Jaafar, "Computers and Education Facebook usage, socialization and academic performance," Computers and Education, vol. 83, pp. 64-73, 2016.

[10] Z. Amin, A. Mansoor, S. R. Hussain, and F. Hashmat, "Impact of Social Media of Student's Academic Performance. ," International Journal of Business and Management Invention, vol. 5, pp. 22-29, 2016.

[11] A. Calvo-Armengol, E. Patacchini, and Z. Yves, "Peer effects and social networks in education," Review of Economic Studies, vol. 76, p. 1239e1267, 2008.

[12] A. M. Helou and N. Z. A. Rahim, "The Influence of Social Networking Sites on Students' Academic Performance in Malaysia," International Journal of Electronic Commerce Studies vol. 5, pp. 247-254, 2014.

[13] N. Tuan and N. Tu, "The Impact of Online Social Networking on Students' Study," VNU Journal of Education Research, vol. 29, pp. 1-13, 2013.

[14] J. Al-Menayes, "Social Media Use, Engagement and Addiction as Predictors of Academic Performance," International Journal of Psychological Studies, vol. 7, pp. 86-94, 2015.

[15] R. A. Bragdon and K. Dowler, "College Student Technology Use and Academic Performance," International Journal of Humanities and Social Science vol. 6, 2016.

[16] S. T. Frein, S. L. Jones, and J. E. Gerow, "When it comes to Facebook there may be more to bad memory than just multitasking," Computers in Human Behavior, vol. 29, p. 2179e2182, 2013.

[17] T. Gok, "The Effects of Social Networking Sites on Students' Studying and Habits," International Journal of Research in Education and Science, vol. 2, pp. 85-93, 2016.
[18] J. A. Paul, M. H. Baker, and J. D. Cochran, "Effect of online social networking on student academic performance," Computers in Human Behavior, vol. 28, p. 2117e2127, 2012.

[19] X. Zheng and M. K. O. Lee, "Excessive use of mobile social networking sites: Negative consequences on individuals," Computers in Human Behavior vol. 65, p. 65e76, 2016.

[20] M. Alatawi, "High School Students as Snappers and Instagramers, and Their Academic Performance," Journal of Emerging Trends in Computing and Information Sciences, vol. 7, 2016.

[21] E. Fori, "The Effects of Social Networking Sites on the Academic Performance of the Engineering Students in the University of Maiduguri, Borno State, Nigeria," International Journal of Computer Science Issues, vol. 13, pp. 76-84, 2016.

[22] D. Mouri and C. Ali-Arshad, "Social networking in Bangladesh: Boon or curse to academic engagement? ," Management and Marketing. Challenges for the Knowledge Society, vol. 11, pp. 380-393, 2016.

[23] P. Thompson, "The digital natives as learners: technology use patterns and approaches to learning," Computers and Education, vol. 65, p. 12e33, 2013.

[24] J. Yeboah and G. D. Ewur, "The Impact of Whatsapp Messenger Usage on Students Performance in Tertiary Institutions in Ghana " Journal of Education and Practice, vol. 5, pp. 157-164, 2014.

[25] N. Gupta, S. Garg, and K. Arora, "Pattern of mobile phone usage and its effects on psychological health, sleep, and academic performance in students of a medical university," National Journal of Physiology, Pharmacy and Pharmacology (India), vol. 6, pp. 132-139, 2016.

[26] J. Li, A. Lepp, and J. E. Barkley, "Locus of control and cell phone use: Implications for sleep quality, academic performance, and subjective well-being," Computers in Human Behavior, vol. 52, pp. 450-457, 2015.

[27] S. Rouis, M. Limayem, and E. Salehi-Sangari, "Impact of Facebook Usage on Students' Academic Achievement: Role of Self-Regulation and Trust," Electronic Journal of Research in Educational Psychology, vol. 9, pp. 961-994, 2011.

[28] L. Lam, "An innovative research on the usage of Facebook in the higher education context of Hong Kong," Electronic Journal of e-Learning, vol. 10, p. 378e386, 2012.

[29] M. K. Kabilan, N. Ahmad, and M. J. Z. Abidin, "Facebook: an online environment for learning of English in institutions of higher education," Internet and Higher Education, vol. 13, p. 179e187, 2010.

[30] V. A. Dickie and H. Meier, "The Facebook tutor: networking education," Ubiquitous Learning, vol. 8, p. $1 \mathrm{e} 12,2015$.

[31] R. González, J. Gasco, and J. Llopis, "Facebook and Academic Performance: A Positive Outcome," Anthropologist, vol. 23, pp. 59-67, 2016.

[32] G. Clough, "Geo-learners: location-based informal learning with mobile and social technologies," IEEE 
Transactions on Learning Technologies, vol. 3, p. 33e44, 2010.

[33] J. J. Liburd and I. M. F. Christensen, "Using web 2.0 in higher tourism education," Journal of Hospitality, Leisure, Sport and Tourism Education, vol. 12, p. 99e108, 2013.

[34] A. C. Karpinski, P. A. Kirschner, I. Ozer, J. A. Mellott, and P. Ochwo, "An exploration of social networking site use, multitasking, and academic performance among United States and European university students," Computers in Human Behavior, vol. 29, p. 1182e1192, 2013.

[35] E. T. Pascarella and P. T. Terenzini, "How college affects students. San Francisco, CA: Jossey-Bass.," 2005.

[36] K. Wong, R. Kwan, K. Leung, and F. L. Wang, "Facebook's potential for personal, social, academic and career development for higher education students," International Journal of Innovation and Learning, vol. 16, p. 203e220, 2014.

[37] I. A. Qureshi, H. Raza, and M. Whitty, "Facebook as elearning tool for higher education institutes," Knowledge Management and E-Learning, vol. 6, p. 440e448, 2014.

[38] R. A. Sanchez, V. Cortijo, and U. Javed, "Students' perceptions of Facebook for academic purposes," Computers and Education, vol. 70, p. 138e149, 2014.

[39] H. Hung and S. C. Yuen, "Educational use of social networking technology in higher education," Teaching in Higher Education, vol. 15, p. 703e714, 2010.

[40] M. Dragan, Z. Dragana, A. Sanela, and M. Isidora, "Exploring students' purposes of usage and educational usage of Facebook," Computers in Human Behavior, vol. 60, p. 441e450, 2016.

[41] H. Sayan, "Affecting Higher Students Learning Activity by Using WhatsApp," European Journal of Research and Reflection in Educational Sciences, vol. 4, pp. 88-93, 2016.

[42] M. Hayes, K. van Stolk-Cooke, and F. Muench, "Understanding Facebook use and the psychological effects of use across generations," Computers in Human Behavior, vol. 49, p. 507e511, 2015.

[43] T. Lisette, "Social networking: a collaborative open educational resource," Computer Assisted Language Learning, vol. 27, p. 149e162, 2014.

[44] A. E. Sobaih and M. Moustafa, "Speaking the same language: the value of social networking sites for hospitality and tourism higher education in Egypt," Journal of Hospitality and Tourism Education, vol. 28, p. 46e 56, 2016.

[45] W. Al-Rahmi, M. Othman, L. Yusof, and M. Musa, "Using social media as a tool for improving academic performance through collaborative learning in Malaysian higher education. ," Review of European Studies, vol. 7, p. $265 \mathrm{e} 273,2015$.

[46] M. N. Hajli and X. Lin, "Developing tourism education through social media," Tourism Planning and Development, vol. 11, p. 405e414, 2014.

[47] S. Jumoke, S. A. Oloruntoba, and O. Blessing, "Analysis of Mobile Phone Impact on Student Academic
Performance in Tertiary Institution," International Journal of Emerging Technology and Advanced Engineering, vol. 5, pp. 361-367, 2015.

[48] L. Burak, "Multitasking in the University Classroom," International Journal for the Scholarship of Teaching and Learning, vol. 6, pp. 1-12, 2012.

[49] H. Al-Tarawneh, "The influence of social networks on students' performance," Journal of Emerging Trends in Computing and Information Sciences, vol. 5, pp. 200205, 2014.

[50] M. D. Griffiths, "Social Networking Addiction: Emerging Themes and Issues," Journal of Addictive Research Therapy, p. 4:e118, 2013

[51] A. T. Alahmar, "The impact of social media on the academic performance of second year medical students at College of Medicine, University of Babylon, Iraq. ," Journal of Medical and Allied Sciences, vol. 6, pp. 77-83, 2016.

[52] S. Naizabekov, "Negative Impact of Social Networking Sites on Academic Performance of Students," 2012.

[53] L. Y. Sahin, "Comparison of users' adoption and use cases of Facebook and their academic procrastination," Digital Education Review, vol. 25, p. 127e138, 2014.

[54] M. I. A. Abusbiha and C. S. Mustaffa, "The relationship between personal factors, Facebook intensity and academic performance of youth students," presented at the The International Conference on communication and Media 2014 (i- COME'14), Libya, Langkawi, MALAYSIA, 2014.

[55] H. Rabiu, A. I. Muhammed, Y. Umaru, and H. T. Ahmed, "Impact of Mobile Phone Usage on Academic Performance Among Secondary School Students in Taraba State, Nigeria," European Scientific Journal January 2016 edition vol. 12, 2016.

[56] J. Mingle, M. Adams, and E. A. Adjei, "A Comparative Analysis of Social Media Usage and Academic Performance in Public and Private Senior High Schools," Journal of Education and Practice, vol. 7, 2016.

[57] M. Kanagarathinam, "Impact of Social Networking Sites on Academic Performance of Adolescents in Coimbatore city," Business Education, vol. 4, 2014.

[58] M. Hooda and A. Tyagi, "A Study of Academic Achievement of Senior Secondary School Students of Haryana State in Relation to Their Facebook Usage," International Journal of Informative and Futuristic Research (IJIFR), vol. 3, pp. 3265-3268, 2016.

[59] T. T. Sandari, "Effects of mobile phone use on academic performance of college going young adults in India," International Journal of Applied Research 2015, vol. 1, pp. 898-905, 2015.

[60] M. Michikyan, K. Subrahmanyam, and J. Dennis, "Facebook use and academic performance among college students: A mixed-methods study with a multi-ethnic sample. ," 2015.

[61] T. El-Badawy and Y. Hashem, "The Impact of Social Media on the Academic Development of School Students," International Journal of Business Administration, vol. 6, pp. 46-52, 2015. 
[62] M. A. Haq and S. Chand, "Pattern of Facebook Usage and its Impact on Academic Performance of University Students: A Gender Based Comparison," Bulletin of Education and Research, vol. 34, pp. 19-28, 2012.

[63] M. Zhou, "Gender difference in web search perceptions and behavior: Does it vary by task performance," Computers and Education, vol. 78, p. 174e184, 2014.
[64] G. C. Lay and U. Balakrishnan, "Students' learning styles and their effects on the use of social media technology for learning," Telematics and Informatics, vol. 33, pp. 808-821, 2016.

[65] A. P. Jomon, M. Hope, H. M. Baker, and J. D. Cochran, "Computers in Human Behavior," 28, vol. 2012, pp. 2117-2127, 2012. 